\title{
EFFECT OF BRAIN BUTTON ON THE DEVELOPMENT OF PRE-SCHOOL CHILDREN IN LAMONGAN, EAST JAVA
}

\author{
Lilis Maghfuroh, Ati'ul Impartina \\ School of Health Sciences (STIKes) Muhammadiyah, Lamongan
}

\begin{abstract}
BACKGROUND: Brain button is a type of brain exercise, which consists of a series of exercises that aims to help brain function better, making the brain sharper and smarter. This exercise starts with putting one hand over the navel. With the thumb and fingers of the other hand, the subject is expected to feel for the two hollow areas under the collarbone, about one inch out from the centre of the chest. Then the subject rubs these areas vigorously for 30 seconds to one minute, from left to right. Brain button stimulates the carotid arteries, which supply freshly oxygenated blood to the brain. This study aimed to test the hypothesis on the effect of brain button on improving development among pre-school children.

SUBJECT AND METHODS: This was a quasi-experimental study, before and after with no control design. A sample of 30 pre-school children from Dharma Wanita Sumber Sari Kindergarten, in Lamongan, East Java, was selected for this study. The independent variable was brain button. The dependent variable was mental development, which was measured by Pre-Screening Development Questionnaire (Kuesioner Pra-Skrining Perkembangan, KPSP). The data was analyzed with Odds Ratio (OR) and McNemar test.

RESULTS: There was an effect of brain button on improving child mental development, although it was not statistically significant. Pre-school children who received brain button were 4 times more likely to have normal development than those who did not receive brain button $(\mathrm{OR}=4.00 ; 95 \% \mathrm{CI}=0.32$ to $50.22 ; \mathrm{p}=0.256)$.

CONCLUSION: The effect of brain button on improving child mental development is in conclusive in this study, as the effect is not statistically significant.
\end{abstract}

Keywords: brain button, mental development, pre-school children 